\title{
What Shapes the Temperatures of Living Rooms in Three European Regions?
}

\author{
Jan Vávra, Vera Peters, Miloslav Lapka, Tony Craig, \\ Eva Cudlínová
}

\begin{abstract}
The paper presents results of a study of heating habits (particularly the reported temperature in the living room during the heating season) in three EU regions: Aberdeenshire in Scotland, Brandenburg state in Germany, and South Bohemia in the Czech Republic. Data were collected using a questionnaire study carried out in 2010. There were approximately 500 respondents in each region. Three types of data are analysed: socio-demographics (including gender, age, education, income); housing characteristics (e.g. type, size, insulation, heating system), and attitudes towards energy and environmental issues (perception of climate change and perceived self-efficacy of energy saving). The results show some explanatory power of income, house insulation, age, place of living and self-efficacy on people's reported living room temperatures. The biggest differences were found, however, between the three regions. Scottish households report the lowest average temperature, Germans higher and Czechs the highest. We also discuss the role of the local climatic conditions and put the results (especially the negligible role of most socio-demographics and housing characteristics) into the framework of theory of social practice and discussions about the limits of traditional sociopsychological ABC models (attitude-behaviour-choice) of pro-environmental behaviours.
\end{abstract}

KEYWORDS Energy saving, environmental behaviour, heating, household, temperature, social practices.

\section{Introduction}

Heat usage is an important element of direct household energy demand and related greenhouse gas emissions. It is influenced by various factors, including local climatic conditions, heating system efficiency, characteristics of the house (insulation, size, type, etc.) and occupant behaviour. This study focuses on reported living room temperatures during the heating season in three European regions: Aberdeenshire in North East Scotland, Brandenburg state in Germany, and South Bohemia in the Czech Republic. The research is based on data from quantitative sociological surveys carried out from January to April 2010 in these three regions. We analyse the self-reported living room heating temperatures and ask to what extent they are influenced by housing infrastructure, socio-demographics, and attitudes towards

Sociálni studia. Department of Sociology FSS MU, 3/2015. S. 135-158. ISSN 1214-813X. 
selected energy and environmental issues. Attention is also paid to the climatic differences between the three regions.

Household heating can be conceptualized as one of the important "environmental behaviours" (Steg and Vlek 2009) or "environmentally significant behaviours" (Stern 2000) because of the significant demand for energy associated with the heating process, especially when fossil fuels are used. Stern's term “environmentally significant behaviour” can also be defined from the actor's point of view as behaviour with an intention to influence the environment (Ščasný, Urban, and Zvěřinová 2013). This definition is closely connected with the term "pro-environmental behaviour" which aims to lower the damage to the environment or even to improve its state (Steg and Vlek 2009). Urban and Ščasný (2012) proved that this interpretation is valid for heating habits. Both understandings of environmental behaviour are important in this paper. The environmental impact of household heating and possible energy curtailment is presented and the effect of indoor heating temperature is discussed. The proenvironmental context of lower temperatures is researched by including respondents' attitudes towards climate change and the efficacy of energy saving.

The empirical work described in this paper includes many variables that have frequently been included in previous research (e.g. Abrahamse and Steg 2009; Kelly et al. 2013). However, the interpretation of the results would be incomplete if the discussion focused only on housing characteristics, socio-demographics and the attitudes or values of the inhabitants. To achieve deeper insight into the issue, we interpret some of the results within the social practice theory of consumption in the discussion (see, e.g. Warde 2005; Shove 2010; GramHanssen 2011).

While some of the empirical research on room temperature and heating habits already employ the social practices paradigm (Gram-Hanssen 2010; Tweed et al. 2014), most of the studies do not (e.g. Karjalainen 2009; Shipworth 2011; Huebner et al. 2013; Kelly 2013). Also, the majority of the above mentioned studies are UK based (e.g. Hunt and Gidman 1982; Gill et al. 2010; Shipworth 2011; Huebner et al. 2013; Kelly 2013; Tweed et al. 2014), with only few exceptions, e.g. a comparison of measured and self-reported temperatures in the US (Lutz and Wilcox 1990), a study on thermal comfort in Finnish homes and offices (Karjalainen 2009), and Swedish research on household heating temperatures (Holgersson and Norlén 1984). ${ }^{1}$ Our study belongs to the minority of research trying to link empirical evidence of heating habits with social practices theory. Furthermore, it is very probably one of the first studies to directly compare reported room temperatures across an international sample of respondents.

\section{Environmental impact of household heating}

Energy used for heating represents a substantial share of the direct energy consumption of households. The exact numbers differ from country to country and are influenced by the

Our literature review is of course limited by our language abilities (English, Czech, German), though the results of the review suggest that the research on heating habits and indoor temperature is widespread especially in the UK. 
definition of the direct/indirect household energy demand. The most urgent environmental aspects of heating are emissions of greenhouse gases (often simply referred to as carbon emissions). However, the link between room temperature and energy demand for heating is neither linear nor straightforward. It is mediated by the external temperature (and other meteorological variables), heating-related habits (such as airing [Gram-Hanssen 2010]), efficiency of the heating system and house insulation (Tweed et al. 2014). The relationship between the final energy demand and carbon emissions is then affected by the heating source - e.g. coal and gas being relatively carbon intensive sources, while solar or wood energy are almost carbon neutral (see, e.g. Vávra and Lapka 2013; Craig et al. 2014).

Residential use is responsible for a relatively high share of the energy consumption in the EU, for example Gram-Hanssen (2010) states that in Denmark one third of overall territorial energy is consumed in residences. According to Lapillone, Pollier and Samci (2014), space heating consumes $67 \%$ of the overall energy consumption for housing (i.e. space and water heating, cooking, cooling and electricity for lightning and appliances) in EU households. All countries in this study are slightly below the EU average with regards to space heating related to direct housing energy: in Germany and the UK space heating accounts for $64 \%$, and in the Czech Republic $62 \%$ (Lapillone, Pollier, and Samci 2014). The carbon emissions of home heating reflect the share of energy demand, being approximately two thirds of the housing emissions in all three countries (HM Government 2009; Klimaktiv n.d.; Vávra and Lapka 2013).

Such a high share of heating energy demand suggests a high potential for energy saving and, consequently, for a drop in carbon emissions. Dietz et al. (2009) estimate that behavioural changes and investments which would cause "little or no reduction in household well-being" (p. 18452) could lower housing and transport greenhouse gas emissions of US households by $20 \%$ (7.4\% of the national emissions). However, "thermostat setbacks" account only for $4.3 \%$ of this possible reduction for households, i.e. $0.9 \%$ of the national emissions. Car transportation related changes, weatherization (insulation) and heating equipment are the major factors. It could be assumed that reductions brought by changing thermostat settings could potentially be relatively higher in Europe, due to the different car fleet and housing insulation standards. The Swedish study by Holgersson and Norlén (1982) estimates that lowering the indoor temperature during heating seasons by $1{ }^{\circ} \mathrm{C}$ can lead to a $7 \%$ decrease of energy consumption in existing houses. Generalization of this information is problematic due to changes in housing efficiency and energy sources over the last three decades.

Although infrastructure factors (heating source, house insulation, etc.) are now important, considering the increasing efficiency of remodelled and new buildings, and the availability of low carbon sources of energy, occupants' behaviour may be even more important in the future. Gill and colleagues (2010) presented a case study on energy demand in new low-energy dwellings in East Anglia. They employed the theory of planned behaviour (Ajzen 1991; Francis et al. 2004 as cited in Gill et al. 2010) and found that $51 \%$ of the variability in heating energy demand can be explained by occupants' behaviour (like thermostat settings, heating with opened windows, etc.). 


\section{Empirical research on household heating}

In his report, Kemna (2014) summarises the indoor reference temperatures (i.e. the official temperatures used for energy-related calculations) for buildings in various EU countries. They range from $18^{\circ} \mathrm{C}$ to $22^{\circ} \mathrm{C}$. Scandinavian states are usually set higher (Sweden $22^{\circ} \mathrm{C}$, Finland $21^{\circ} \mathrm{C}$ ), southern countries (Spain, Italy, Portugal) are set at $20^{\circ} \mathrm{C}$ and Western states show the lowest reference temperature of $18-19^{\circ} \mathrm{C}$ in the UK, Germany, Austria and France. The official recommended indoor temperature in the Czech Republic is $20^{\circ} \mathrm{C}$ (TZB-INFO n. d.). Obviously, the real household temperatures can differ from the official reference temperatures which are listed above.

When focusing on empirically researched room temperature, we can start the review with the older case study of Swedish households (Holgersson and Norlén 1982). The average room temperature weighted to be representative for Sweden as a whole was $21.6^{\circ} \mathrm{C}$ (measured between February and May). The authors found that apartments in multi-family houses showed higher temperatures than single-family houses. Similarly, a higher indoor temperature was typical for pensioners or households with small children. There was no effect of the age of the building, however.

In 1990, Lutz and Wilcox presented the results of a comparison between measured temperatures and self-reported thermostat settings of US respondents living in detached houses in California. The average indoor temperature during the heating seasons was $21^{\circ} \mathrm{C}$ during the daytime, while the self-reported setting of the thermostat was only $19.9^{\circ} \mathrm{C}$. The real temperature was always higher than the self-reported temperature; the minimum difference was found in the evening $\left(0.6^{\circ} \mathrm{C}\right)$, while the maximum was found at night $\left(2.6^{\circ} \mathrm{C}\right)$.

Hunt and Gidman (1982) presented the results of a large UK survey: the average temperature in the living room was $18.3^{\circ} \mathrm{C}$ during the heating season. Other rooms were often significantly colder. Newer houses and houses with central heating (not to be mistaken with district heating) had higher indoor temperatures than older houses or houses without central heating. Scottish houses had lower room temperatures than the rest of the UK; households with children were significantly warmer, while households with elderly people were often colder. Higher income was associated with slightly higher temperatures and considerably less difference in temperature between rooms.

Shipworth (2011) looked back and compared thermostat settings of English households in 1984 and 2007. She found that the thermostat setting did not change significantly (varying in the range $19-20^{\circ} \mathrm{C}$ ), though the reported temperature of living rooms and halls increased between 1986 and 1996. She argued that people did not demand higher temperature, but the energy demand was higher in 1996 due to different technologies (central heating being more common now) and possibly also due to more space being heated (rooms which were kept cold are now heated, more conservatories/sunrooms, etc.) or windows being opened while heating. The expected drop in energy demand for households (due to increased efficiency) seems to have been substituted by a significant direct rebound effect (take-back), though not due to a higher temperature demand, but due to different practices, technology and "building demographics".

A study of Huebner et al. (2013), focused on household room temperature in England in $2007 / 2008$. The average measured temperature was $19.5^{\circ} \mathrm{C}$. The study also pointed to the 
changes in use of heating (and subsequently temperature) during the 24-hour cycle. The heating was more often on during the morning and evening, while mostly off during the night.

Kelly and colleagues (2013) provided statistical analysis of the same sample of respondents and found many factors which influenced the final indoor temperature. North East England (geographically close to Scotland) had the lowest temperatures in England. Households with more inhabitants, higher income, lower outdoor temperatures, children at home, people over 64, and tenants recorded higher temperatures than did households with contrasting characteristics. The authors argued that owners also often tend to live in less efficient houses, thus they probably lower the temperature due to higher relative costs. Better roof insulation, efficiency of the walls or double glazing increase the temperature; apartments are usually warmer than semi-detached houses (which showed higher room temperatures than detached houses). Residents of newer houses reported higher temperatures than residents of older houses. Occupants with routine energy habits (regular heating patterns) report higher temperatures than those without such habits. Most of the results correspond with the Hunt and Gidman study (1982), with the exception of the apparent differences in temperature of households with older people. An explanation for the conflicting results regarding the role of age might be the shift in habits and standards of the older generations over the last 30 years. Kelly et al. argue that older people spend more time at home and prefer warmer conditions, while the older respondents in the Hunt and Gidman study might still have been brought up in more sparing conditions. On the other hand, even today, older people are still more often endangered by the "old and cold" syndrome - i.e. insufficient heating due to various reasons (e.g. Day and Hitchings 2011). ${ }^{2}$

Expanding the focus of enquiry beyond room temperature, there are interesting studies on the wider spectrum of thermal comfort related behaviour, especially with regards to the UK. Some of these studies bring deeper insight into the motivation of residents ${ }^{3}$ behaviour. Tweed et al. (2014) used mixed methods (including the measurement of temperature and qualitative interviews) to understand the thermal comfort practices of South Wales residents. They found that they homeowners were very active in thermal comfort management ${ }^{3}$ and that indoor temperature is not necessarily correlated with energy demand, due to the characteristics of the building or to residential practices.

Another of the few examples of non-UK research is the paper by Gram-Hanssen (2010) which presents the analysis of qualitative interviews with inhabitants of a Copenhagen suburb. All participants of this case study lived in the same kind of houses with the same source of energy for heating (district heating). This allowed the author to compare their energy demand and discuss the factors which influence that demand. Heating behaviour (setting of

2 There is a large body of literature on the relationship of heating and low income and fuel poverty. Due to the limited space and scope of this paper, we leave this field aside (see, e.g. Anderson, White and Finney 2012; Bouzarovski 2014).

3 The importance of active thermal comfort management was supported by a Finish case presented by Karjalainen (2009). The primary action performed by respondents when feeling uncomfortably cold is to put on more clothes (over $50 \%$ of respondents); adjusting the thermostat or putting more firewood into the fireplace were each chosen by only approx. $20 \%$ of respondents. 
the thermostat and airing) was associated with many factors, including economic, environmental attitudes, habits from previous housing (or childhood), previous experiences (energy crisis in the 1970s), etc. Similar to the case of Tweed et al. (2014), energy demand was not driven only by the temperature, but also by airing habits, which seem to be an underestimated driver of higher energy consumption. Gram-Hanssen emphasised four components of energy demand: technology (how the house is built and equipped); embodied habits (e.g. childhood experience, relation to other habits, experience from one's work); rules and knowledge (information gained from different sources and for various reasons); and meaning and engagement (e.g. importance of environmental or economic reasons or the importance of having a cosy and welcoming home).

Investigating the influence of socio-demographics, we refer to the research of Abrahamse and Steg (2009) who, in their Dutch study, found that direct and indirect household energy use was influenced mainly by socio-demographics: higher energy demand correlates with larger household size (more members) and higher income. But when it came to implementing energy savings measures, psychological factors were found to be more important. Higher levels of perceived behavioural control (ability to save energy) were associated with higher energy savings, while a higher perceived level of joint responsibility for energy-related environmental problems was related - quite surprisingly - to lower energy savings. Awareness of the negative consequences associated with energy use was not a significant predictor when controlling for other psychological factors and socio-demographics.

Using a larger international sample, Urban and Ščasný (2012) provide empirical support regarding the importance of attitudes (environmental concern) in predicting energy-saving behaviour. Analysing samples from nine OECD countries (including Australia, Canada, the Czech Republic, France, Italy, Netherlands, Korea, Norway and Sweden) they found that in all countries (except Sweden) most respondents always or often turn down heating when leaving the room. Higher environmental concern was an important predictor of higher occurrence of this behaviour in all countries; the effect of socio-demographics was weak and different in the individual countries.

\section{Heating as social practice}

Most of the empirical research mentioned above focused on the technology or infrastructure, socio-demographic characteristics or psychological motivations (attitudes, norms, values) that are related to household room temperature. Only Gram-Hanssen (2010) and to some extent Tweed et al. (2014) considered social practices in their investigation. We do not seek to imply that there are no other empirical studies dealing with social practices, but rather that their quantity is much lower than those in line with the traditional, socio-psychological research that concentrates on factors that directly influence behaviour at the individual level (Moezzi and Janda 2014). In contrast, social practice approaches are more focussed on collectively shared habits, know-how and meanings.

There is not one agreed upon definition of social practice. With respect to household energy demand, Gram-Hanssen defines practice as "a collection of sayings and doings performed by individuals but formed and sustained by collectively shared elements" (2011: 75). 
Understanding of social practices related to energy demand is well elaborated by Shove (2010). She puts the paradigm of social practices in opposition to the traditional sociological and psychological understanding of environmentally significant behaviour (in her case climate change-related behaviour) labelled by Shove the "ABC model" (attitude - behaviour choice). She questions the idea that attitudes are drivers of behaviours and she emphasises social practices. ${ }^{4}$ According to Shove (2010), the ABC model tries to find ways to influence people's attitudes, which should then result in pro-environmental behaviours and choices. This happens in the context of external factors, which also influence (hinder or support) the individual changes of behaviour. Shove argues that the values or attitudes are not internal per se. They are reproduced by social practices in the complex environment of our everyday lives. With this viewpoint it is in fact impossible to differentiate between the internal values and attitudes and external (contextual) barriers or motivators of pro-environmental behaviour, as the traditional $\mathrm{ABC}$ model does in both academia and practical policies. As Shove states "...conventions that are often taken to constitute the context of behaviour have no separate existence: rather, they are themselves sustained and changed through the ongoing reproduction of social practice. In the language of $\mathrm{ABC}$, the driver and the driven are as one" (2010: 1279).

When applied to the example of household temperatures, the traditional $\mathrm{ABC}$ model asks: Which values, attitudes, and socio-demographic characteristics influence one's behaviour, i.e. the setting and maintaining of the heating temperature in the household? What infrastructure (external context) affects a person's choice of behaviour and its consequence (heating temperature)? The review of the empirical research (see above) includes many of these questions. Despite being to some extent critical of the ABC model, we contend that it has provided a framework from which many useful and interesting findings have emerged. Indeed, it could be argued that the so-called ABC model is more of a characterisation of the rather simplistic uptake of psychological findings in the policy domain as opposed to a serious critique of psychological models of human behaviour - many of which place considerable emphasis on person-environment transactions. Lazarus (1991) is critical of accounts of human behaviour that place too much emphasis on either the person or the context, suggesting that models of human experience need to understand both the individual and the context, in relation to any given situation. Models characterised by $\mathrm{ABC}$ thinking arguably over-emphasise the individual component of person-environment transactions, and are not able to present a more complex and nuanced picture of the situation.

It is possible that the analysed phenomena, in our case the heating of the living room to a certain temperature, are carried through the households and society as a habit or long term social practice, regardless of values, attitudes, socio-demographics and external (physical) context. Preferred room temperature is also tightly connected with the perception of thermal comfort. When referring to practices as "shared elements", we can stress the aspect of bodily

4 Following her argumentation, it is obvious that the need for energy is not an objective factor, the need is socially constructed. We may also argue that when any energy policy documents try to estimate the energy demand in the future and adapt the energy production abilities for this demand, they in fact co-create this future possible demand. 
habit and know-how as Gram-Hanssen presents it $(2010,2011)$. She stresses the influence of the learning process and socialization. Wallenborn and Wilhite (2014) point to the importance of the body and the physical experience of life, which is often neglected in social science: The practice aspect of choosing and maintaining room temperature can possibly explain the differences in patterns or temperature profiles found when comparing across houses, which cannot be explained by the $\mathrm{ABC}$ models and techno-environmental factors. Individuals (or the whole age cohort) can be raised in some conditions (e.g. poor housing insulation and expensive heating) which contribute to their maintaining a low room temperature. Even though the conditions (insulation, energy price) change over time, the individual or society maintains a practice of setting low household temperatures. Future generations could be brought up with the experience of lower temperatures being perceived as something normal and would probably be more likely to maintain such practices. Social practices are in general quite stable, but they are, of course, also subject to change.

When it comes to the change of practices (and behaviours), theorists of social practice bring more complex picture of the issues than the ABC model. As Shove argued (2010), the distinction between the driver and the driven is blurred. Wallenborn and Wilhite (2014) are also critical about the traditional attitude - behaviour consequence and offer some cases when a change in practice can lead to changes in attitudes or beliefs. Such change can be brought about through a new experience, either social or individual (the oil crisis in the 1970s, blackouts, moving to a new apartment, the birth of a child, etc.).

These theoretical considerations also have implications for environmental and energy policies. Shove and Walker (2014) point to the fact that most of the current energy-related research deals with problems of resource efficiency, new technologies and low carbon transition. The need for energy is usually taken for granted. Since any energy use is accompanied (or caused) by some human activity, the policies of energy transition will also ultimately influence these social practices. Energy use is deeply entrenched in society and this fact should not be neglected. Walker (2014) stresses the fact that energy is not consumed "as such", but rather that the consumption depends on technologies and practices (p. 49). When stressing the social context of the energy demand, he claims, we should ask "what energy is being used for" (p. 50). ${ }^{5}$

Moezzi and Janda (2014) elaborate on the new concept of the "social potential" of energy saving in buildings. They also point to the limits of the "at home" behavioural changes (and limits of success of such campaigns), as people spend considerable time in nondomestic situations such as institutional, company, transport, or industrial settings.

\section{Our research questions}

We use the data obtained by a questionnaire survey in three European regions to tackle three research questions:

5 She interestingly turns around the classical sociological and psychological problem of the value action gap: "...after all the gap is only mystifying if we suppose that values do (or should) translate into action" (Shove 2010: 1276). 
1. Are there any differences between reported living room temperatures during the heating season in the three regions/countries?

2. Do the traditional $\mathrm{ABC}$ and infrastructure variables (housing and environmental characteristics, socio-demographics, and attitudes) explain the variability of living room temperatures?

3. Can the concept of social practices help to explain some of the variability of living room temperatures between houses?

\section{Methods}

Study sites

The results are based on the quantitative analysis of the data collected through a questionnaire field study in the three regions in January - April 2010 as a part of the larger international 7 EU FP research project GILDED which focused on the possibilities for decreasing household energy demand. ${ }^{6}$ In each country one region with an urban centre and rural surroundings was chosen and a total of 1,519 respondents were surveyed (482 in Aberdeenshire, 537 in Brandenburg, and 500 in South Bohemia). The sampling procedure combined random and quota sampling to achieve relative representativeness of the sample. Personal questioning and drop \& collect methods were used in all countries, along with postal questionnaires in Scotland for some of the respondents.

The Scottish site consists of the city of Aberdeen (population approximately 230,000) and the rural areas of Aberdeenshire (pop. 200,000) in North East Scotland, an area with low population density. The average temperatures in winter range between $2^{\circ}$ (night) and $6^{\circ} \mathrm{C}$ (day); in summer between $11^{\circ}$ and $17^{\circ} \mathrm{C}$. The city of Potsdam (pop. 150,000) and the Potsdam-Mittelmark district (pop. 205,000) represent the study sites in Germany. These can be found in the northeast part of the country in the Bundesland Brandenburg, former East Germany. In the coldest month of winter (February), the average temperatures range between $-1^{\circ}$ and $3^{\circ} \mathrm{C}$, summer temperatures are usually $14^{\circ}-24^{\circ} \mathrm{C}$. In the Czech Republic the research area consists of the city of České Budějovice (pop. 95,000) and rural municipalities from the former administrative districts České Budějovice and Český Krumlov (pop. 145,000). The research area belongs to the South Bohemian Region, an administrative unit with a relatively low population density and a rural character compared to the rest of the Czech Republic. The average winter temperatures are $-3^{\circ}$ to $4^{\circ} \mathrm{C}$ and average temperatures in summer are between $13^{\circ}$ and $26^{\circ} \mathrm{C} .^{7}$

Regarding the political and economic history of the countries, Scotland, as a part of UK, is the typical "Western" country and long-term EU member. Brandenburg used to be part of socialist East Germany, which was reunited with the West Germany in 1990. The Czech Republic was a part of socialist Czechoslovakia. It underwent economic transformation after 1989 (and split into the Czech Republic and Slovakia in 1993). For detailed information about all of the study sites see Gotts and Kovách (2010). When labelling the regions of our

For more information about the project see, http://gildedeu.hutton.ac.uk/.

Average temperatures for all three regions are based on data from http://www.worldweatheronline.com/. 
study, we use Aberdeenshire, Brandenburg and South Bohemia, but use the national labels Scottish, German and Czech - for the respondents, though the samples are not nationally representative.

\section{Sampling and questionnaire}

The respondents provided information about their socio-demographic characteristics, attitudes towards energy use and climate change, and information about their households, houses and energy relevant habits. For the socio-demographics and some information about the infrastructures of the houses see Table 1. The purpose of the original project was to compare the urban and rural regions. This caused overrepresentation of the rural respondents in our sample (approx. 50:50). However, as the results suggest, this is not such a big problem in terms of the reported living room temperature. Apart from this characteristic, our sample is relatively representative for the regional populations of people older than 18 years, though slightly more educated than the regional populations. The role of some socio-demographics factors (e.g. gender or education) as explanatory variables is limited to some extent in our case study, as we ask for the living room temperature in the shared space of the whole household.

The crucial information for our study is the self-reported heating temperature as answered in the question What is your average temperature during heating times in your living room when you are at home? The questionnaire offered categories from $18^{\circ}$ to $24^{\circ} \mathrm{C}$. Categories "less than $18^{\circ} \mathrm{C}$ " or "more than $24^{\circ} \mathrm{C}$ " were recoded as $17^{\circ} \mathrm{C}$ and $25^{\circ} \mathrm{C}$ respectively, for the purpose of Analysis of variance (ANOVA) and Ordinary least squares (OLS) regressions. ${ }^{8}$ We are aware of the potential bias caused by the inaccuracy of the selfreported behaviour (Lutz and Wilcox 1990) and the potential effect of the official reference indoor temperatures (Kemna 2014; TZB-INFO n. d.) and focus on this problem in our discussion.

In addition to the socio-demographic and housing characteristics presented in Table 1, the information about the heating source (see below), age of the heating system and insulation of the house/apartment were obtained from the respondents. The information on the household's net income was converted into "equivalent income". The average net income per person was weighted ${ }^{9}$ and divided into the quintiles for each country. Regarding the insulation, respondents were asked whether they have any of these six types of insulation: insulation of the loft, filled cavity wall, insulation of underfloor, insulation of solid walls, double glazing or two windows, and window insulation against draughts. This information was further simplified for the analysis.

It should be said that this lowers the real variance of household temperatures, as there is a substantial number of the households who report lower temperatures than $18^{\circ} \mathrm{C}$ in Aberdeenshire (see Figure 1). Lower temperatures were also reported by UK research (e.g. Hunt and Gidman 1982; Kelly et al. 2013).

9 The calculation of equivalent income followed the OECD-modified scale, see http://www.oecd.org/ els/soc/OECD-Note-EquivalenceScales.pdf. However, due to a lack of data we had to use a simplified weighting procedure: first household member $=1$, every other member $=0.5$. 
Table 1: Information about the sample of respondents

\begin{tabular}{|c|c|c|c|c|}
\hline \multirow{3}{*}{ Region } & & \multirow{2}{*}{$\begin{array}{c}\text { Aberdeenshire } \\
47.5 \%\end{array}$} & \multirow{2}{*}{$\begin{array}{c}\text { Brandenburg } \\
54.0 \%\end{array}$} & \multirow{2}{*}{$\begin{array}{c}\text { South Bohemia } \\
50.2 \%\end{array}$} \\
\hline & Urban & & & \\
\hline & Rural & $52.5 \%$ & $46.0 \%$ & $49.8 \%$ \\
\hline \multirow{2}{*}{ Gender } & Male & $54.2 \%$ & $54.1 \%$ & $48.5 \%$ \\
\hline & Female & $45.8 \%$ & $45.9 \%$ & $51.5 \%$ \\
\hline \multirow{2}{*}{ Education } & Lower than university & $61.7 \%$ & $58.5 \%$ & $82.4 \%$ \\
\hline & University & $38.3 \%$ & $41.6 \%$ & $17.6 \%$ \\
\hline \multirow{5}{*}{$\begin{array}{l}\text { Household } \\
\text { type }\end{array}$} & Single household & $20.6 \%$ & $13.8 \%$ & $15.3 \%$ \\
\hline & Living together with partner & $44.7 \%$ & $40.1 \%$ & $34.7 \%$ \\
\hline & $\begin{array}{l}\text { Living together with partner } \\
\text { and children }\end{array}$ & $27.5 \%$ & $36.0 \%$ & $42.2 \%$ \\
\hline & Single parent & $4.0 \%$ & $5.2 \%$ & $5.5 \%$ \\
\hline & Other & $3.2 \%$ & $4.8 \%$ & $2.3 \%$ \\
\hline \multirow{3}{*}{$\begin{array}{l}\text { Employment } \\
\text { status }\end{array}$} & Employed & $50.1 \%$ & $56.8 \%$ & $63.9 \%$ \\
\hline & Retired & $40.0 \%$ & $28.3 \%$ & $20.4 \%$ \\
\hline & Other & $9.9 \%$ & $14.9 \%$ & $15.7 \%$ \\
\hline \multicolumn{2}{|c|}{ Mean age (SD) } & $55.6(14.58)$ & $50.3(15.00)$ & $44.8(15.11)$ \\
\hline \multicolumn{2}{|c|}{ Mean number of people in household (SD) } & $2.37(1.11)$ & $2.61(1.11)$ & $2.69(1.16)$ \\
\hline \multirow{3}{*}{$\begin{array}{l}\text { Type of } \\
\text { dwelling }\end{array}$} & House & $85.3 \%$ & $58 \%$ & $49.8 \%$ \\
\hline & Apartment in 2-3 story house & $14 \%$ & $23.6 \%$ & $19.4 \%$ \\
\hline & $\begin{array}{l}\text { Apartment in multi-story house } \\
+ \text { other type }\end{array}$ & $0.6 \%$ & $18.4 \%$ & $30.8 \%$ \\
\hline \multirow{2}{*}{ Ownership } & Owner & $89 \%$ & $61 \%$ & $65 \%$ \\
\hline & Tenant & $11 \%$ & $39 \%$ & $35 \%$ \\
\hline \multicolumn{2}{|c|}{ Mean size of the dwelling in $\mathrm{m}^{2}$ (SD) } & $123(23.5)$ & 119 (58.0) & $97(64.4)$ \\
\hline \multicolumn{2}{|c|}{ Mean year of construction (SD) } & $1970(28)$ & $1951(33)$ & $1974(30)$ \\
\hline \multicolumn{2}{|l|}{$\mathbf{N}$} & 482 & 537 & 500 \\
\hline
\end{tabular}

Note: Percent are valid percent, SD stands for standard deviation of the mean, $\mathrm{N}$ for the number of respondents.

Respondents were also asked for their attitudes towards climate change and energy use, inspired mostly by the items used in the Heath and Gifford (2006) study. We use seven of these questions to create two constructs: Perception of climate change (abbreviated as Perception of CC) and Self-efficacy of energy saving. Both of these complex variables were previously tested to be reliable and good explanatory variables for the behavioural intention towards mitigation of climate change (Heath and Gifford 2006). Six of these questions were asked on the traditional 1 to 5 Likert scale of agreement with the offered statement ( 1 = I strongly disagree; $5=$ I strongly agree). For one question the Likert scale gradated the degree of importance of climate change as a global problem $(1=$ Not serious at all; $5=$ Very serious). Both of the constructs are means of the responses in both sets of questions. 
The Perception of CC consists of four questions: I think that human lifestyles are a major contributor to any present-day climate change. The main causes of any present-day climate change are emissions caused by humans. Importance of climate change as a global problem. Too much emphasis has been placed on climate change. The last question was recoded as an opposite (some questions were phrased negatively to avoid response sets). Alpha reliability of the construct ranges between 0.687 and 0.758 for the three countries.

The construct Self-efficacy of energy saving consists of these three questions: I think I can contribute to tackling climate change by saving energy. It is pointless to save energy to tackle climate change (recoded). I think it is useful to save energy to tackle climate change. Alpha reliability of the construct ranges between 0.613 and 0.781 . In both cases the values of alpha are seen as sufficient to indicate reliable constructs: Perception of CC and Self-efficacy of energy savings

\section{Statistical analysis}

Statistical analysis of the data was performed using SPSS Statistics 19. The ANOVA Fisher and Brown-Forsythe tests were applied on the comparison of mean temperatures of the groups sorted by countries or types of heating. Living room heating temperature was then used as a dependent variable in OLS regression. The threshold of statistical significance for all tests was $5 \%$. For the purpose of the regression, some categories of the independent variables were simplified and/or dummy variables were created $(1=$ yes, $0=$ no). Variables which were already dichotomous are: area (urban/rural), gender, education, ownership (owner/tenant) and age of the heating system (10 or less years/more than 10). Age was collapsed into three age groups $(18-39,40-59,60+)$. Household type was transformed into the presence of children at home ( $1=$ yes, $0=$ no). Employment status was recoded into three categories: employed, retired, other (including unemployed and homemaker). Five groups of income quintiles were used. Type of dwelling was simplified into dichotomy house/other (including apartment in 2-3 story or multi-story house). The age of the house was divided into three categories: built before 1970, between 1970 and 1990, after 1991. Similarly, the size of the dwelling was categorized: $<100 \mathrm{~m}^{2}, 100-139 \mathrm{~m}^{2},>140 \mathrm{~m}^{2}$. Implemented insulation measures were categorized into four groups: loft, underfloor, wall (including both cavity and solid walls), and windows (including both double/two windows and window draught insulation). Number of types of insulation was then used as a count variable (0 for no insulation, 4 for all measures). Number of people in household, Perception of CC and Selfefficacy of energy savings were used as scale variables.

\section{Results}

Before we present the results of the statistical analysis of the questionnaire data, we present some contextual information about the regions studied. The statistics shed a light on the different national contexts and are thus helpful for the interpretation of the data (see Table 2). The table shows that there is almost no difference between the number of heating 
degree days ${ }^{10}$ in the Aberdeen region and South Bohemia, while the demand for heating in the state of Brandenburg is more than $10 \%$ lower. According to Lapillone, Pollier and Samci (2014), the average heating demand of households $\left(\mathrm{kWh} / \mathrm{m}^{2} /\right.$ year) is almost the same in the regions of Aberdeen and Brandenburg, and slightly higher in South Bohemia. Relative expenditures on direct household energy demand (including heating and electricity) were lowest in the Scottish region, followed by the German region and highest in the Czech region (European Commission 2014).

Table 2: Information about the regions

\begin{tabular}{|l|c|c|c|}
\hline & Aberdeenshire & Brandenburg & South Bohemia \\
\hline Heating degree days per year & 3,490 & 3,034 & 3,427 \\
\hline Average heating demand $\left(\mathrm{kWh} / \mathrm{m}^{2} /\right.$ year) & 146.6 & 147.9 & 160.0 \\
\hline Expenditures on household energy & $4.0 \%$ & $7.6 \%$ & $10.3 \%$ \\
\hline
\end{tabular}

Note: Heating degree days are for NUTS 2 regions: Aberdeen City, Aberdeenshire and North East Moray (Scotland); Brandeburg - Southwest (Germany); Southwest (Czech Rep.). Data are for year 2009, obtained from Eurostat (2013). Average heating demand for year 2012 (Lapillone et al. 2014: 15). Expenditures on household energy include solid fuels, liquid fuels, district heating, gas and electricity used directly in the households. The percent show the share from the overall household expenditures. Data are Eurostat Consumer Price Statistics for 2008 (European Commission 2014: 127). Since the data for heating demand and expenditures are accessible only for the country average, we weighted them according to the ratio of NUTS 2 region and country number of heating degree days. This means that the differences in temperatures in the regions are reflected, though the differences in the regional housing structure and characteristics or average regional incomes are not.

The mean reported living room temperature in heating season varies in the three surveyed regions: $18.9^{\circ} \mathrm{C}$ in Aberdeenshire, $20.7^{\circ} \mathrm{C}$ in Brandenburg and $21.7^{\circ} \mathrm{C}$ in South Bohemia. The means are in fact trimmed means: regarding the fact that the lowest category is $17^{\circ} \mathrm{C}$ and includes lower temperatures and $25^{\circ} \mathrm{C}$ is the highest category and also includes higher temperatures. Considering the frequency of the answers, the real room temperature would be probably slightly lower in Aberdeenshire and slightly higher in South Bohemia. There was a significant effect of region on living room temperature: $F(2,1396.714)=$ 379.181, $\mathrm{p}=0.000 .{ }^{11}$ Figure 1 shows the distribution of heating temperatures among the regions. While in Aberdeenshire $84 \%$ of households have temperatures lower than or equal to $20^{\circ} \mathrm{C}\left(27 \%\right.$ lower than $\left.18^{\circ} \mathrm{C}\right), 85 \%$ of households in Brandenburg fit into the range $19^{\circ}-$ $22^{\circ} \mathrm{C}$. South Bohemian households have the highest living room temperature with $77 \%$ of them being greater than or equal to $21^{\circ} \mathrm{C}\left(14 \%\right.$ with the temperature higher than $23^{\circ} \mathrm{C}$, compared to $1 \%$ in both of other surveyed regions).

10 A measurement on the severity of cold and consequent demand for heating. It is based on the length of the heating season and outdoor temperature (see, e.g. Eurostat 2013).

11 For this and further ANOVA calculations, the numbers in brackets represent the degrees of freedom, $\mathrm{p}$ stands for significance. 
Figure 1: Frequency of the temperatures of living rooms in the regions

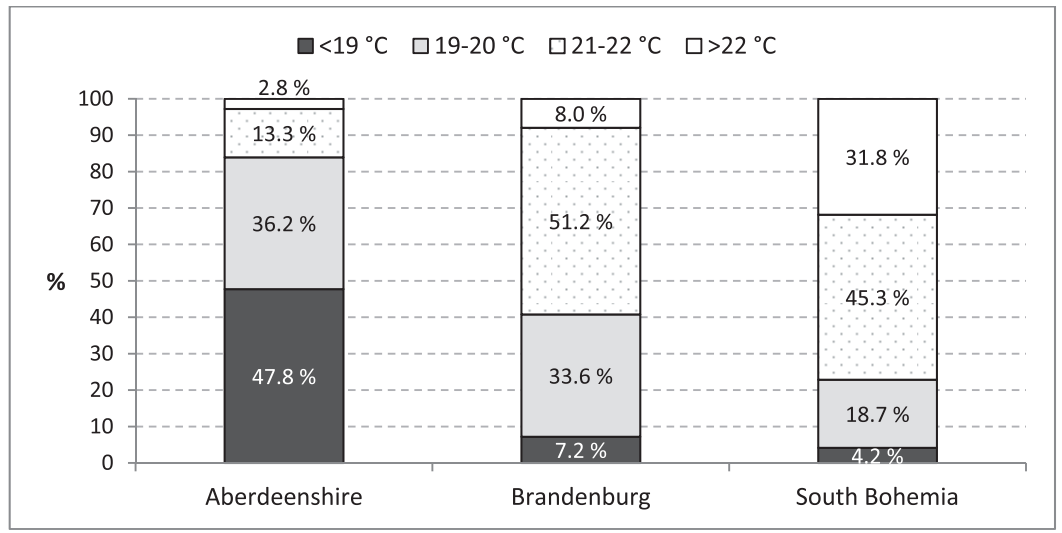

One potentially important factor which could influence the heating temperature is the heating source, i.e. the type of heating fuel. This is due to the different costs of fuel, the varying difficulty of maintaining thermal comfort and other reasons. This factor, similarly to real heating demand, is not included in the following regression analysis, due to the high amount of missing data. ${ }^{12}$ However, we test the effect of the heating source on the heating temperature for those respondents who provided the data (Aberdeenshire $\mathrm{N}=265$; Brandenburg $\mathrm{N}=305$; South Bohemia $\mathrm{N}=255$ ). Overall there were no significant differences in room temperature associated with the use of natural gas, heating oil, electricity, district heating, coal and wood as sources of heat. The F values of ANOVA tests were not significant in Aberdeenshire: $\mathrm{F}(2,248)=0.769, \mathrm{p}=0.464$.); Brandenburg: $\mathrm{F}(2,270)=0.647, \mathrm{p}=0.524)$; or South Bohemia: $F(4,245)=0.663, p=0.618$.). Thus, the type of heating source was not found to be an important factor for the final living room temperature.

The mean number of insulation (see Table 3) is lower in South Bohemia than in Aberdeenshire or Brandenburg. When considering the differences between houses and apartments, and owners and tenants (i.e. both respondents who live in houses and property owners indicated more insulation), this is also caused by the significantly higher share of houses and owners in the Scottish sample. Respondents who didn't know about their insulation were omitted from the analysis due to missing values. This decreased the number of respondents in the regression (see Table 4), but lowered potential bias.

The number of cases used in the regression models is unfortunately lower than the original sample sizes due to some missing values (rather than replacing them by mean or other statistics, we decided to follow the listwise deletion). Twenty nine to forty one percent of the respondents were excluded from the regression analysis in the particular countries. See Table 1 for the original size of the samples and Table 4 for the number of respondents analysed by the regression. However, the sample is not biased significantly; the average living room

12 This would substantially lower the number of respondents included in the OLS regression, when the cases are deleted listwise. 
temperature is $19^{\circ} \mathrm{C}$ in Aberdeenshire, $20.8^{\circ} \mathrm{C}$ in Brandenburg, and $21.8^{\circ} \mathrm{C}$ in South Bohemia and the differences between respondents included in the regression and those left out is not significant in any of the regions.

Table 3: House insulations

\begin{tabular}{|l|c|c|c|}
\hline & Aberdeenshire & Brandenburg & South Bohemia \\
\hline Loft & $86 \%$ & $70 \%$ & $47 \%$ \\
\hline Underfloor & $12 \%$ & $18 \%$ & $22 \%$ \\
\hline Walls & $32 \%$ & $62 \%$ & $46 \%$ \\
\hline Windows & $98 \%$ & $78 \%$ & $92 \%$ \\
\hline Mean number of insulations (SD) & $2.27(0.78)$ & $2.28(1.02)$ & $2.06(1.01)$ \\
\hline $\begin{array}{l}\text { Mean number of insulation (house/other } \\
\text { dwelling) }\end{array}$ & $2.38 / 1.53$ & $2.39 / 2.08$ & $2.43 / 1.69$ \\
\hline Mean number of insulation (owner/tenant) & $2.30 / 2.00$ & $2.40 / 2.02$ & $2.33 / 1.54$ \\
\hline
\end{tabular}

Note: Percent show the share of households which have the particular insulation measure installed. SD stands for standard deviation of the mean.

Model 1 includes respondents from all countries as one sample. Region/country is the most important explanatory factor. Living in Brandenburg increases the average reported living room temperature by $1.7^{\circ} \mathrm{C}$ and in South Bohemia by $2.7^{\circ} \mathrm{C}$ compared to being settled in Aberdeenshire. A significant linear effect of income is also suggested: by trend a higher income leads to higher room temperatures. Self-efficacy of energy saving is a significant predictor for lower room temperatures, but looking at the country-specific regressions this effect is caused mostly by the Czech respondents. Other factors are not statistically significant. The model with all regions shows a good explanatory power of $39 \%$ of the variability of living room temperatures. Most of the explanatory power results from the regional differences, thus, when the samples are divided into the regional models, the results of the regression are still statistically significant, but much worse (explaining 5-8\% of the variability). In the Scottish case, only higher income leads to higher temperatures and the significance is on the edge of the $5 \%$ threshold. Income is a very strong predictor of living room temperature in Brandenburg (higher income - higher temperature). Higher living room temperature is also reported by respondents with better insulation and the older generation. Contrarily, urban respondents tend to have colder living rooms. The Czech sample shows exactly the same pattern regarding income as the German sample and higher temperature is reported by retired respondents. Czech respondents are the only group with a significant effect of attitudes. A higher perceived self-efficacy of energy saving leads to lower temperatures.

The aggregate insulation index is a significant predictor of living room temperature only in the Brandenburg region. 
Table 4: Regression models (dependent variable: living room temperature during heating season)

\begin{tabular}{|c|c|c|c|c|c|c|c|c|}
\hline & \multicolumn{2}{|c|}{$\begin{array}{l}\text { Model 1: } \\
\text { All regions }\end{array}$} & \multicolumn{2}{|c|}{$\begin{array}{c}\text { Model 2: } \\
\text { Aberdeenshire }\end{array}$} & \multicolumn{2}{|c|}{$\begin{array}{c}\text { Model 3: } \\
\text { Brandenburg }\end{array}$} & \multicolumn{2}{|c|}{$\begin{array}{c}\text { Model 4: } \\
\text { South Bohemia }\end{array}$} \\
\hline & B & $\beta$ & B & $\beta$ & B & $\beta$ & B & $\beta$ \\
\hline \multicolumn{9}{|l|}{ Region (ref: Aberdeenshire) } \\
\hline Brandenburg & 1.747 & $0.410^{* *}$ & - & - & - & - & - & - \\
\hline South Bohemia & 2.679 & $0.646 * *$ & - & - & - & - & - & - \\
\hline Area $(0=$ Rural, $1=$ Urban $)$ & -0.108 & -0.027 & 0.336 & 0.095 & -0.400 & $-0.145^{*}$ & -0.231 & -0.072 \\
\hline Gender $(0=$ Female, $1=$ Male $)$ & 0.105 & 0.027 & 0.080 & 0.023 & 0.118 & 0.043 & 0.154 & 0.049 \\
\hline \multicolumn{9}{|l|}{ Age (ref: 18-39) } \\
\hline $40-59$ & 0.110 & 0.028 & 0.043 & 0.012 & 0.051 & 0.019 & 0.157 & 0.049 \\
\hline $60+$ & 0.442 & 0.103 & 0.702 & 0.195 & 0.834 & $0.286^{*}$ & -0.598 & -0.152 \\
\hline Number of people in household & 0.115 & 0.067 & 0.062 & 0.039 & 0.121 & 0.098 & 0.149 & 0.111 \\
\hline $\begin{array}{l}\text { Children in household }(0=\text { No, } \\
1=\text { Yes })\end{array}$ & 0.071 & 0.018 & 0.440 & 0.119 & 0.031 & 0.011 & 0.084 & 0.026 \\
\hline \multicolumn{9}{|l|}{ Employment (ref: Employed) } \\
\hline Retired & 0.144 & 0.033 & 0.187 & 0.051 & -0.447 & -0.150 & 1.083 & $0.281^{*}$ \\
\hline Other & 0.129 & 0.021 & 0.354 & 0.059 & 0.129 & 0.030 & 0.072 & 0.016 \\
\hline $\begin{array}{l}\text { Education ( } 0=\text { Lower, } 1= \\
\text { University) }\end{array}$ & -0.189 & -0.045 & -0.195 & -0.054 & -0.098 & -0.036 & -0.049 & -0.012 \\
\hline \multicolumn{9}{|l|}{ Income (ref: $1^{\text {st }}$ quintile) } \\
\hline $2^{\text {nd }}$ quintile & 0.291 & 0.057 & -0.042 & -0.009 & 0.483 & $0.152^{*}$ & 0.442 & 0.094 \\
\hline $3^{\text {rd }}$ quintile & 0.735 & $0.148^{* *}$ & 0.653 & $0.153^{*}$ & 0.834 & $0.249^{* *}$ & 0.647 & $0.152 *$ \\
\hline $4^{\text {th }}$ quintile & 0.532 & $0.110^{* *}$ & 0.258 & 0.057 & 0.646 & $0.171^{*}$ & 0.728 & $0.207^{* *}$ \\
\hline $5^{\text {th }}$ quintile & 0.874 & $0.177^{* *}$ & 0.707 & $0.165^{*}$ & 0.784 & $0.233^{* *}$ & 1.277 & $0.307^{* *}$ \\
\hline Perception of climate change & -0.112 & -0.044 & -0.041 & -0.018 & -0.135 & -0.066 & -0.026 & -0.012 \\
\hline Self-efficacy of energy saving & -0.214 & $-0.076^{*}$ & -0.268 & -0.101 & -0.005 & -0.002 & -0.290 & $-0.131 *$ \\
\hline Dwelling ( $0=$ Other, $1=$ House $)$ & -0.269 & -0.064 & -0.549 & -0.111 & -0.152 & -0.052 & -0.250 & -0.079 \\
\hline \multicolumn{9}{|l|}{ House age (ref < 1970) } \\
\hline $1970-1990$ & 0.051 & 0.012 & 0.170 & 0.048 & 0.135 & 0.031 & -0.083 & -0.025 \\
\hline$>1991$ & 0.153 & 0.034 & 0.179 & 0.041 & 0.046 & 0.016 & 0.234 & 0.061 \\
\hline \multicolumn{9}{|l|}{ Dwelling size $\left(r e f:<100 \mathrm{~m}^{2}\right)$} \\
\hline $100-139 \mathrm{~m}^{2}$ & 0.054 & 0.013 & -0.718 & -0.203 & 0.058 & 0.021 & 0.336 & 0.084 \\
\hline$>140 \mathrm{~m}^{2}$ & -0.012 & -0.003 & -0.516 & -0.142 & -0.249 & -0.084 & 0.116 & 0.027 \\
\hline Owner $(0=$ No, $1=$ Yes $)$ & 0.102 & 0.022 & 0.407 & 0.064 & 0.389 & 0.128 & -0.094 & -0.029 \\
\hline $\begin{array}{l}\text { Age of heating system }(0=>10 \\
\text { years, } 1=\leq 10 \text { years) }\end{array}$ & 0.153 & 0.037 & 0.039 & 0.009 & 0.191 & 0.069 & 0.151 & 0.047 \\
\hline Insulations & 0.082 & 0.039 & 0.242 & 0.108 & 0.205 & $0.149^{*}$ & -0.072 & -0.046 \\
\hline CONSTANT & $19.015^{* *}$ & & $19.003^{* *}$ & & $19.658^{* *}$ & & $21.844^{* *}$ & \\
\hline ADJUSTED R ${ }^{2}$ & \multicolumn{2}{|c|}{0.388} & \multicolumn{2}{|c|}{0.046} & \multicolumn{2}{|c|}{0.080} & \multicolumn{2}{|c|}{0.067} \\
\hline $\mathbf{N}$ & \multicolumn{2}{|c|}{1010} & \multicolumn{2}{|c|}{344} & \multicolumn{2}{|c|}{315} & \multicolumn{2}{|c|}{351} \\
\hline
\end{tabular}

Note: OLS regression, enter method, missing cases deleted listwise. Significance levels $* \mathrm{p}<0,05 ; * * \mathrm{p}<0,01$; $* * p<0,001$. B is unstandardized and $\beta$ standardized regression coefficient; $\mathrm{N}$ represents the number of cases. Adjusted $\mathrm{R}^{2}$ is coefficient of determination, showing the quality of the model. If multiplied by 100 , it expresses the portion of data variability explained by the regression model. 


\section{Discussion}

When compared to some previous studies (e.g. Hunt and Gidman 1982; Kelly et al. 2013), the explanatory power of most of the socio-demographics and infrastructural factors is much weaker. One possible interpretation is that this is due to differences in measurement. Many of the studies reviewed above measured the actual room temperature directly, while we asked the respondents to report it. Naturally, self-reported behaviour is prone to biases. First, when the temperature is taken from the thermostat, it does not necessarily represent the real room temperature as this can also be influenced by airing habits, opened/closed doors between rooms with different temperatures, etc. Second, the perceived (reported) temperature can differ from the real temperature (see e.g. Lutz and Wilcox 1990). This is may be a limitation of our study, yet it does bring up an interesting question: to what extent are people able to assess room temperature and how much is this assessment influenced by "what is perceived as the normal room temperature"? This question is provoking especially in relation to the countries' official indoor reference temperatures for buildings (see above), which show similar order as the results of our quantitative study (colder in Aberdeenshire and Brandenburg and warmer in the South Bohemia). Such a potential bias towards a perceived norm could explain why the variance between different population groups appears to be lower overall in our study, i.e. the explanatory power of socio- and housing-demographics on room temperature is weaker than in other studies, especially than in the study of Kelly et al. (2013). Yet some of the nonsignificant results in Aberdeenshire (higher room temperatures in households with children and older people or with installed insulation measures) are in line with their UK research. It is clear then, that the data our study is based on does not represent a precise measurement, but the comparison of our results to previous UK research, including the average temperature, suggests that the self-reported information is not that biased, at least in the case of the Scottish data.

The considerable effect of income confirms the important economic motivation for setting room temperature, i.e. households with more money tend to have a higher living room temperature. Similarly, the temperature increases along with higher numbers of insulation measures in Brandenburg (and by a non-significant trend also in Scotland). When compared internationally, the effect of insulation is more complex - Scottish and German dwellings are on average insulated similarly, but the reported temperature in Germany is significantly higher. Other housing characteristics not included in our survey could be important as well, for example the thickness of non-insulated walls.

The effect of older age is very interesting. People over 60 tend to have a higher living room temperature in Aberdeenshire, though the result is not significant, but there is no effect of being retired. In Brandenburg, respondents over 60 report significantly higher temperatures, but opposed to that finding retired tend to have insignificantly lower temperatures. The situation is totally opposite among the Czech respondents (retired people have significantly higher and over 60 insignificantly lower temperatures).

The respondent's perceived self-efficacy of energy saving was a significant predictor of room temperature only for the Czech sample, which suggests that in this region the awareness of energy use manifests itself in heating habits, as opposed to the other two regions and contrary to the previous Dutch study of Abrahamse and Steg (2009). We can argue that lowering 
the temperature setting in the living room can be interpreted as pro-environmental behaviour only among the Czech respondents.

When trying to interpret the regional differences, for which no explanation is offered by socio- and building-demographics, we can relate it to the national average data, weighted for the regions (see Table 2). The natural conditions of Aberdeenshire and South Bohemia show different patterns, but the number of heating degree days were almost the same (higher than in Brandenburg). However, the relative expenditures on household energies were more than two times lower in Aberdeenshire than in South Bohemia. It seems that the financial motives, though they are important, are not able to fully explain the situation. Here we would like to refer back to the social practice theory. Room temperature can be interpreted as a relatively stable long-term social practice, shaped by many external factors (natural conditions, housing characteristics, expenditures on energy, value of saving money, etc.) and internalized through growing up in and sharing of certain temperature conditions. In Aberdeenshire, as in the rest of the UK, the practice of relatively cold homes was established and remains, even though, compared to Germany and Czech Republic, the relative price of energy is not that high (and is lower than it used to be).

When looking back on recent Czech history, we found that the relative price of energy (using natural gas as an example) doubled between 1989 and 2011 (Staníček n.d.). Certain heating practices may have solidified when energy prices were lower. This can be supported by the fact that, of the regions in our study, South Bohemia has the highest share of households living in the multi-story houses and the highest share of homes heated with central heating. Most of these houses are high-rise constructions built from prefabricated concrete slabs in the 1970s and 1980s. Heating meters were not mandatory in Czechoslovakia and the Czech Republic until 2015 and were not commonly installed until mid-1990s. The expenditures on heating were calculated by the size of apartment in the multi-story houses ${ }^{13}$ and thermostatic radiator valves were not used. There is a lot of anecdotal evidence that in some cases the setting of radiators did not work at all and people had overheated apartments during the winter and always had to have the windows opened. A higher room temperature may have been embedded as a stable social practice under these conditions. However, our data do not indicate differences in living room temperatures of the households living in houses or apartments in South Bohemia now. This suggests that the social practice may not have been limited to a certain housing style (many people change their dwelling during their lifetime or their children do not live in the same type of house) and was really socially shared. When comparing the expenditures on different types of energy sources, Ščasný, Urban and Zvěřinová (2013) show that the expenditure on gas increased from $1.5 \%$ of all household expenditures in 1993 to $4 \%$ in 2009 . However, expenditures on district heating merely fluctuated $(3.7 \%$ in 1993 , $4.2 \%$ in 2003 and $3 \%$ in 2009), probably also due to increased efficiency of heating systems and insulation in multi-story houses. Considering this, the differences in energy source prices

13 Even in 2015, the legislation required that $40-50 \%$ of the house heating demand had to be calculated by the size of the apartments and only 50-60\% regarding the real consumption of the particular apartment (using the meters). 
do not appear to be that important for Czech citizens; most of them keep similar room living temperatures.

We concentrated most on the Czech case, comparing it to both the Scottish region and the neglected German region. Even though the surveyed former East German region experienced historical socialist conditions comparable to those of the Czech Republic, living room temperature there is considerably lower. The social practice of heating seems to have been shaped differently, which might be explained by different factors. First, the population of the city of Potsdam has changed quite considerably since the end of the former East Germany in 1990; many people from West Germany have moved to the city, so social practices connected to energy consumption in the GDR are less wide spread. This migration applies to a much lesser extent, however, in the analysed rural regions in Potsdam-Mittelmark. Secondly, energy prices per unit are relatively high in Germany and thirdly, especially since the educational campaigns of the 1980s, people have evolved and become quite aware of their (direct) energy use. National statistics support the notion that people use heating energy rather economically: the heating energy demand of German households declined considerably between 1990 and 2013 (Umweltbundesamt 2013). It seems that the social norm of using energy thoughtfully has shaped the practice of heating and results in rather moderate room temperatures. The lack of difference between the urban and rural areas suggests that both price and educational motivation have had a stronger impact than the West-East migration.

While financial motives (and lack of control) are important in the development of the social practice of setting room temperatures, annual temperature variation is also a possible (and to some extent also probable) motive. As Kemna (2014) and TZB-INFO (n. d.) show, the Scandinavian countries and the Czech Republic have higher official reference room temperatures, while the UK and Germany have lower. Following this, we can argue that people in countries with higher temperature variation during the year heat their homes more than those with lower differences. Similarly it can be said that the heating temperature in winter is driven by the normal summer temperature. ${ }^{14}$ These environmental interpretations fit perfectly in our three regions: Aberdeenshire has the lowest variation, the lowest summer temperature and lowest living room temperature, Brandenburg is in the middle and South Bohemia shows the highest variation and the highest temperatures. The "objective need" expressed as the number of heating degree days (see Table 2) is less important. The environmental factors are not in contradiction with the theory of social practice, however. The social practices of maintaining certain indoor temperatures can then possibly be traced deeper into history and be more embedded in the web of the society.

On the policy level, entrenched social practices can hinder the lowering of overall energy demand and climate change mitigation. Being used to certain, especially if relatively high, room temperatures can lead to higher energy demand when the housing standards increase. Efficiency is also increasing, but higher need has some effect. As Lapillone and colleagues (2014) show, the energy demand for heating decreased in the EU countries, but there was $20 \%$ take-back (direct rebound effect) due to the increasing size of dwellings (especially

14 We would like to thank to the anonymous reviewer for this idea. 
in new EU countries). Shipworth (2011) also described similar take-back in predicted UK energy savings. In this case, construction of larger dwellings or heating to higher temperature was not directly the cause, instead the take-back was caused by heating more rooms to the temperature of the living room than they had been decades ago (see above). Social practices of room temperatures could also hinder the proposed "behavioural wedges", which would cause "little or no reduction in household well-being" (Dietz et al. 2009). Lowering the temperature can reduce the perceived well-being much more than the objectivist approach expects.

In addition, related social practices, such as those relating to clothing have a direct impact on the level of required energy demand, as the overall insulation levels of clothing are considered to be lower today than they were when many of the thermal comfort standards were established (see Shove 2003).

Contrarily there is also pro-environmental potential in the theory of social practice. When behavioural or values oriented campaigns fail (attitudes had no effect, except in the Czech case), the more social practice focused approaches can succeed. But as theorists of social practice argue, such change could then be much deeper than the changes from unilateral top-down campaigns. Lower room temperature could be promoted as a part of deeper and wider sustainability and as such it could enable individuals to think about many other aspects of their personal and social energy use.

\section{Conclusion and suggestions for future research}

We conclude that there are significant differences regarding the living room temperatures between the three surveyed regions, with the lowest average temperature in households of Aberdeenshire, a higher temperature in Brandenburg and the highest average living room temperature in South Bohemia. The explanatory power of housing and environmental characteristics, socio-demographics, and attitudes is limited. Household income is a significant predictor in all regions; insulation, older age and urbanity show a significant effect only in Brandenburg, while self-efficacy of energy saving and retirement status only in South Bohemia. According to the results of our study, it is questionable to what extent the heating, or at least the setting of indoor heating temperature, can be interpreted in the framework of environmental or pro-environmental behaviour. We argue that the embedded social practices along with geographical and climate differences probably offer a better account of the variability in living room temperatures and are useful for its interpretation. This is not to suggest that heating should not be seen as one of the top priorities in household-oriented environmental and energy policies. The very opposite is true, household heating is very important, considering its environmental impact. But simple solutions in this domain are hard to come by, and the desired changes need to be put into wider social context, which exceeds the "environmental protection by individual's choice" discourse.

Despite the limits of our research outcomes due to the self-reported character of the information, the regional scale of the case studies, and the interpretation of some nationally average data, the results bring further questions and research areas. As was mentioned in the literature review, some empirical studies have already considered the social practices 
approach, but these are primarily qualitative case studies with low numbers of participants. It is often possible to link household energy demand to practices, but it is impossible to state any broader conclusions. Including the questions on the heating practices or childhood experience into the quantitative research (possibly international) could bring very interesting results. Further analyses of the relationship between measured and self-reported temperatures can also show how precise people are in their assessment and whether there are some socio-demographic or national biases. This would be helpful for future quantitative studies; it is easier (and considerably less expensive) to obtain a self-reported temperature than to put a data logger into every household. Research on indoor temperature variability throughout the year and its comparison with both outdoor temperature variability and sociological variables is another potentially interesting field of inquiry. As income is an important explanatory factor, the real price of energy and relative household expenditures on energy should be included in the questionnaires or interviews. Apart from the suggestions for quantitative research, more qualitative data is needed as well, be it a longer ethnographic study of heating practices (Hargreaves 2011) which links the general understanding of energy and environment with particular energy use in the households (Fischer et al. 2012) or similar case studies as applied, for example, in the case of electricity consumption (Westkog and Winther 2014).

\section{Acknowledgements}

The data were collected during the $7^{\text {th }}$ EU FP project GILDED (no. 225383). The authors would like to acknowledge all participants of the survey. Jan Vávra and Eva Cudlínová also acknowledge the support of the project Postdoc USB (reg.no. CZ.1.07/2.3.00/30.0006) realised through the EU Education for Competitiveness Operational Programme and funded by the European Social Fund and the Czech state budget.

\section{References}

ABRAHAMSE, Wokje and Linda STEG. "How Do Socio-demographic and Psychological Factors Relate to Households' Direct and Indirect Energy Use and Savings?” Journal of Economic Psychology 30(5): 711-720.

ANDERSON, Will, Vicki WHITE and Andrea FINNEY. 2012. "Coping with Low Incomes and Cold Homes." Energy Policy 49: 40-52.

BOUZAROVSKI, Stefan. 2014. "Energy Poverty in the European Union: Landscapes of Vulnerability." Wiley Interdisciplinary Reviews: Energy and Environment 3(3): 276-289.

CRAIG, Tony, J. Gary POLHILl, Ian DENT, Carlos GALAN-DIAZ and Simon HESLOP. 2014. "The North East Scotland Energy Monitoring Project: Exploring Relationships between Household Occupants and Energy Usage." Energy and Buildings 75: 493-503.

DAY, Rosie and Russell HITCHINGS. 2011. "'Only Old Ladies Would Do That': Age Stigma and Older People's Strategies for Dealing with Winter Cold." Health \& Place 17(4): 885-894.

DIETZ, Thomas, Gerald T. GARDNER, Jonathan GILLIGAN, Paul C. STERN and Michael P. VANDENBERGH. 2009. "Household Actions Can Provide a Behavioral Wedge to Rapidly Reduce US Carbon Emissions." Proceedings of the National Academy of Sciences 106(44): 18452-18456. 
EUROPEAN COMMISSION. 2014. Commission Staff Working Document: Energy Prices and Costs Report. SWD (2014)20 final/2. Brussels: European Commission. Retrieved September 24, 2015 (http://ec.europa.eu/energy/sites/ener/files/documents/20140122_swd_prices.pdf).

EUROSTAT. 2013. Heating Degree-Days by NUTS 2 Regions - Annual Data. Retrieved June 20, 2015 (http://appsso.eurostat.ec.europa.eu/nui/show.do?dataset=nrg_esdgr_a).

FISCHER, Anke, Vera PETERS, Mirjam NEEBE, Jan VÁVRA, Antoinette KRIEL, Miloslav LAPKA and Boldizsár MEGYESI, B. 2012. "Climate Change? No, Wise Resource Use Is the Issue: Social Representations of Energy, Climate Change and the Future." Environmental Policy and Governance 22(3): 161-176.

GILL, Zachary M., Michael J. TIERNEY, Ian M. PEGG and Neil ALLAN. 2010. “Low-Energy Dwellings: The Contribution of Behaviours to Actual Performance." Building Research \& Information 38(5): 491-508.

GOTTS, Nick and Imre KOVÁCH. 2010. Climate Change and Local Governance: Alternative Approaches to Influencing Household Energy Consumption. A Comparative Study of Five European Regions. Budapest: Institute of political science of Hungarian Academy of Science. Retrieved January 10, 2015 (http://mek.oszk.hu/09300/09355/09355.pdf).

GRAM-HANSEN, Kirsten. 2010. "Residential Heat Comfort Practices: Understanding Users.” Building Research \& Information 38(2): 175-186.

GRAM-HANSEN, Kirsten. 2011. "Understanding Change and Continuity in Residential Energy Consumption." Journal of Consumer Culture 11(1): 61-78.

HARGREAVES, Tom. 2011. "Practice-ing Behaviour Change: Applying Social Practice Theory to ProEnvironmental Behaviour Change.” Journal of Consumer Culture 11(1): 79-99.

HEATH, Yuko and Robert GIFFORD. 2006. "Free-Market Ideology and Environmental Degradation: The Case of Belief in Global Climate Change." Environment and Behavior 38(1): 48-71.

HM GOVERNMENT. 2009. The UK Low Carbon Transition Plan. National Strategy for Climate and Energy. The Stationery Office. Retrieved June 19, 2015 (https://www.gov.uk/government/uploads/ system/uploads/attachment_data/file/228752/9780108508394.pdf).

HOLGERSSON, Margareta and Urban NORLÉN. 1984. "Domestic Indoor Temperatures in Sweden." Building and Environment 19(2): 121-131.

HUEBNER, Gesche M., Megan MCMICHAEL, David SHIPWORTH, Michelle SHIPWORTH, Mathieu DURAND-DAUBIN and Alex SUMMERFIELD. 2013. "Heating Patterns in English Homes: Comparing Results from a National Survey against Common Model Assumptions.” Building and Environment 70: 298-306.

HUNT, D. R., and M. I. GIDMAN. 1982. “A National Field Survey of House Temperatures.” Building and Environment 17(2): 107-124.

KARJALAINEN, Sami. 2009. "Thermal Comfort and Use of Thermostats in Finnish Homes and Offices." Building and Environment 44(6): 1237-1245.

KEMNA, René. 2014. Average EU building heat load for HVAC equipment. Final Report. Delft: Van Holsteijn en Kemna B.V. (VHK). Retrieved September 24, 2015 (https://ec.europa.eu/energy/sites/ ener/files/documents/2014_final_report_eu_building_heat_demand.pdf).

KELLY, Scott, Michelle SHIPWORTH, David SHIPWORTH, Michael GENTRY, Andrew WRIGHT, Michael POLLITT, Doug CRAWFORD-BROWN and Kevin LOMAS. 2013. "Predicting the Diversity of Internal Temperatures from the English Residential Sector Using Panel Methods." Applied Energy 102: 601-621.

KLIMAKTIV. n.d. “CO 2 Rechner.” Retrieved December 21, 2014 (http://klimaktiv.klimaktiv-co2rechner.de/de_DE/page/). 
LAPILLONNE, Bruno, Karine POLLIER and Nehir SAMCI. 2014. Energy Efficiency Trends for Households in the EU. Enerdata. Retrieved June 22, 2015 (http://www.odyssee-mure.eu/publications/ efficiency-by-sector/household/household-eu.pdf).

LAZARUS, Richard S. 1991. Emotion and Adaptation. New York: Oxford University Press.

LUTZ, James and Bruce A. WILCOX. 1990. "Comparison of Self Reported and Measured Thermostat Behavior in New California Houses." Proceedings of the 1990 ACEEE Summer Study on Energy Efficiency in Buildings 2: 91-100. Retrieved June 23, 2015 (http://aceee.org/files/proceedings/1990/ data/papers/SS90_Panel2_Paper14.pdf).

MOEZZI, Mithra and Kathryn B. JANDA. 2014. "From 'If Only' to 'Social Potential' in Schemes to Reduce Building Energy Use.” Energy Research \& Social Science 1: 30-40.

SHIPWORTH, Michelle. 2011. "Thermostat Settings in English Houses: No Evidence of Change between 1984 and 2007." Building and Environment 46(3): 635-642.

SHOVE, Elizabeth. 2003. "Converging Conventions of Comfort, Cleanliness and Convenience." Journal of Consumer Culture 26(4): 395-418.

SHOVE, Elizabeth. 2010. "Beyond the ABC: Climate Change Policy and Theories of Social Change." Environment and Planning A 42(6): 1273-1285.

SHOVE, Elizabeth and Gordon WALKER. 2014. "What Is Energy For? Social Practice and Energy Demand." Theory, Culture \& Society 31(5): 41-58.

STANÍČEK, Petr. n.d.. Za Komunistů Jsme Se Měli Lépe...?? Retrieved December 20, 2014 (http://www. zakomunistu.cz/).

STEG, Linda and Charles VLEK. 2009. "Encouraging Pro-environmental Behaviour: An Integrative Review and Research Agenda." Journal of Environmental Psychology 29(3): 309-317.

ŠČASNÝ, Milan, Jan URBAN and Iva ZVĚǨINOVÁ. 2013. Environmentally Significant Behaviour in the Czech Republic: Energy, Food and Transportation. Prague: Karolinum Press.

TZB-INFO. n. d. "Vnitřní výpočtové teploty dle ČSN EN 12831 a doporučené relativní vlhkosti vzduchu dle ČSN 06 0210.” Retrieved June 20, 2015 (http://vetrani.tzb-info.cz/tabulky-a-vypocty/28-vnitrnivypoctove-teploty-dle-csn-en-12831-a-doporucene-relativni-vlhkosti-vzduchu-dle-csn-06-0210).

TWEED, Christopher, Dylan DIXON, Emma HINTON and Karen BICKERSTAFF. 2014. "Thermal Comfort Practices in the Home and their Impact on Energy Consumption." Architectural Engineering and Design Management 10(1-2): 1-24.

URBAN, Jan and Milan ŠČASNÝ. 2012. "Exploring Domestic Energy-Saving: The Role of Environmental Concern and Background Variables." Energy Policy 47: 69-80.

VÁVRA, Jan and Miloslav LAPKA. 2013. "Size Matters: Climate Change Perception and Carbon Footprint of Czech Households." Culturologia 2(2): 18-25.

WARDE, Alan. 2005. "Consumption and Theories of Practice." Journal of Consumer Culture 5(2): $131-153$.

WALLENBORN, Grégoire and Harold WILHITE. 2014. "Rethinking Embodied Knowledge and Household Consumption." Energy Research \& Social Science 1: 56-64.

WALKER, Gordon. 2014. "The Dynamics of Energy Demand: Change, Rhythm and Synchronicity." Energy Research \& Social Science 1: 49-55.

WESTKOG, Hege and Tanja WINTHER. 2014. "Electricity Consumption: Should There Be a Limit? Implications of People's Attitudes for the Forming of Sustainable Energy Policies." Consilience: The Journal of Sustainable Development 11(1): 97-14.

UMWELTBUNDESAMT. 2013. "Endenergieverbrauch der privaten Haushalte.” Retrieved September 24, 2015 (https://www.umweltbundesamt.de/daten/private-haushalte-konsum/energieverbrauchder-privaten-haushalte). 


\section{Authors}

Jan Vávra received his $\mathrm{MA}$ and $\mathrm{PhD}$ at Faculty of Arts, Charles University in Prague. Currently he works at the Faculty of Economics, University of South Bohemia in České Budějovice. His research is primarily focused on the social perception of environmental problems, energy demand and carbon footprint of households, food-self provisioning, economic alternatives and other aspects of sustainability.

Contact: jan.vavra@prirodou.cz

Vera Peters is environmental sociologist focused on the perception of environmental issues (mostly climate change), energy demand and carbon footprint of households. She is currently a $\mathrm{PhD}$ student in Potsdam Institute of Climate Impact Research.

Contact: Vera.Peters@pik-potsdam.de

Miloslav Lapka's field of interest is environmental sociology and landscape ecology. Since 2010, he has been involved in the Faculty of Economics, University of South Bohemia in České Budějovice and Faculty of Arts, Charles University in Prague. He has published more than 100 scientific papers in the field of environmental and social sciences. His latest work is the monograph Towards an Environmental Society? Concepts, Policies, Outcomes (2012). Contact:miloslav.lapka@centrum.cz

Tony Craig is an environmental psychologist working in the Social, Economic and Geographical Sciences group of The James Hutton Institute on the theme of values choices and behaviour. His work focuses on the relationship between psychological factors and environmental behaviour.

Contact: tony.craig@hutton.ac.uk

Eva Cudlinová graduated from the University of Economics, Prague. Since 2007 she has been head of the Department of Regional Management, Faculty of Economics, University of South Bohemia in České Budějovice. She is interested in environmental and ecological economics. She is currently primarily involved in the study of bioeconomy and green economy/ growth.

Contact: evacu@centrum.cz 